\title{
Peranan Komoditas Tanaman Pangan Unggulan terhadap Kesempatan Kerja dan Pendapatan di Kabupaten Sukoharjo (Analisis Input-Output)
}

\section{The Role of Leading Food Crop Commodities toward Job Opportunities and Income in Sukoharjo Regency (Input-Output Analysis)}

\author{
Tuminem $^{1}$, Suprapti Supardi ${ }^{2}$, dan Minar Ferichani ${ }^{3}$ \\ ${ }^{1}$ Program Pascasarjana Agribisnis Universitas Sebelas Maret \\ Jl. Ir. Sutami No. 36A, Surakarta, Indonesia \\ ${ }^{2}$ Program Studi Agribisnis Universitas Sebelas Maret \\ Jl. Ir. Sutami No. 36A, Surakarta, Indonesia \\ Email : tumi.ferryanto@gmail.com
}

Diterima : 5 September 2018

Revisi : 6 Oktober 2018

Disetujui : 12 Desember 2018

\begin{abstract}
ABSTRAK
Subsektor tanaman pangan merupakan subsektor yang strategis. Selain menyerap tenaga kerja terbesar dalam kegiatan produksi, subsektor tanaman pangan juga menghasilkan produk yang menjadi bahan pangan pokok bagi sebagian besar masyarakat Indonesia. Penelitian ini bertujuan untuk mengidentifikasi komoditas tanaman pangan unggulan dan menganalisis peranan komoditas tanaman pangan unggulan tersebut terhadap kesempatan kerja dan pendapatan di Kabupaten Sukoharjo. Data yang digunakan adalah data produksi komoditas tanaman pangan tahun 2011-2015 Kabupaten Sukoharjo dan Jawa Tengah serta data tabel input-output Kabupaten Sukoharjo tahun 2012 transaksi total atas dasar harga produsen. Metode analisis menggunakan Location Quotient (LQ), Shift Share Analysis (SSA), dan Input-Output (IO). Hasil penelitian menunjukkan bahwa padi, kedelai, dan kacang tanah merupakan komoditas basis di Kabupaten Sukoharjo. Padi, jagung, dan kedelai tumbuh cepat tetapi hanya padi yang memiliki daya saing sehingga menjadi komoditas unggulan di Kabupaten Sukoharjo. Berdasarkan analisis angka pengganda, padi memiliki angka pengganda pendapatan tertinggi yaitu sebesar 0,0325 sedangkan angka pengganda kesempatan kerja padi peringkat ketiga setelah jagung dan kacang-kacangan.

kata kunci: tanaman pangan, pengganda pendapatan, pengganda kesempatan kerja.
\end{abstract}

\section{ABSTRACT}

Food crop is a strategic sub-sector. Besides absorbing labor in production activities, food crops sub-sector also produces staple food for most of the Indonesian people. This study aims to determine leading food crop commodities and to analyze the role of it toward job opportunities and income in Sukoharjo Regency. This study used the data on the production of food crops in 2011-2015 Sukoharjo Regency and Central Java Province and Input-Output Table of Total Transaction Based on Producer Price in Sukoharjo Regency at 2012. The results showed that paddy, soybeans, and peanuts were the base commodities in Sukoharjo Regency. Paddy, corn, and soybeans were growing fastly, but only paddy had competitiveness so that it becomes a leading commodity in Sukoharjo Regency. Based on multiplier analysis, paddy has the highest income multiplier compared to other food crop commodities, which is 0.0325 , whereas the number of employment multipliers ranked third after corn and beans.

keywords: food crop, employment multiplier, job opportunities multiplier

\section{PENDAHULUAN}

$\mathrm{M}$ enurut pandangan ekonomi pembangunan, tujuan utama dari pembangunan ekonomi bukan hanya meningkatkan pertumbuhan ekonomi yang setinggi-tingginya tetapi juga menghapuskan atau mengurangi tingkat kemiskinan, penanggulangan ketimpangan pendapatan, dan penyediaan lapangan kerja 
dalam konteks perekonomian yang terus berkembang (Nurman, 2015). Pembangunan pertanian menjadi salah satu bagian dari pembangunan ekonomi yang mempunyai tujuan tidak hanya mengejar tingkat produksi pertanian yang tinggi tetapi juga meningkatkan taraf hidup dan kesejahteraan petani serta menyerap tenaga kerja. Meskipun kontribusi sektor pertanian di suatu negara mengalami penurunan, sektor pertanian tetap mempunyai peran penting dalam menyediakan lapangan kerja yang besar (Giap Tan, dkk., 2015). Ratarata penduduk Indonesia yang bekerja di sektor pertanian selama periode 2011-2016 mencapai 38,73 juta orang dan merupakan yang tertinggi dibandingkan sektor lain seperti pada Gambar 1. dalam menentukan biaya hidup di Indonesia sedemikian rupa, sehingga memungkinkan pangsa biaya tenaga kerja dalam struktur biaya produksi barang dan jasa tergolong terendah di dunia (Saragih, 2010). Dalam UU Nomor 18 Tahun 2012 tentang Pangan, disebutkan bahwa penyelenggaraan pangan bertujuan untuk meningkatkan kemampuan memproduksi pangan secara mandiri, menyediakan pangan yang beraneka ragam, dan memenuhi persyaratan keamanan, mutu, dan gizi bagi konsumsi masyarakat, mewujudkan tingkat kecukupan pangan, terutama pangan pokok dengan harga yang wajar dan terjangkau sesuai dengan kebutuhan masyarakat. Selain itu juga untuk mempermudah atau meningkatkan akses pangan bagi masyarakat, terutama masyarakat

Gambar 1. Rata-rata Jumlah Penduduk 15 Tahun ke Atas yang Bekerja menurut Lapangan Pekerjaan Utama di Indonesia, 2011-2016

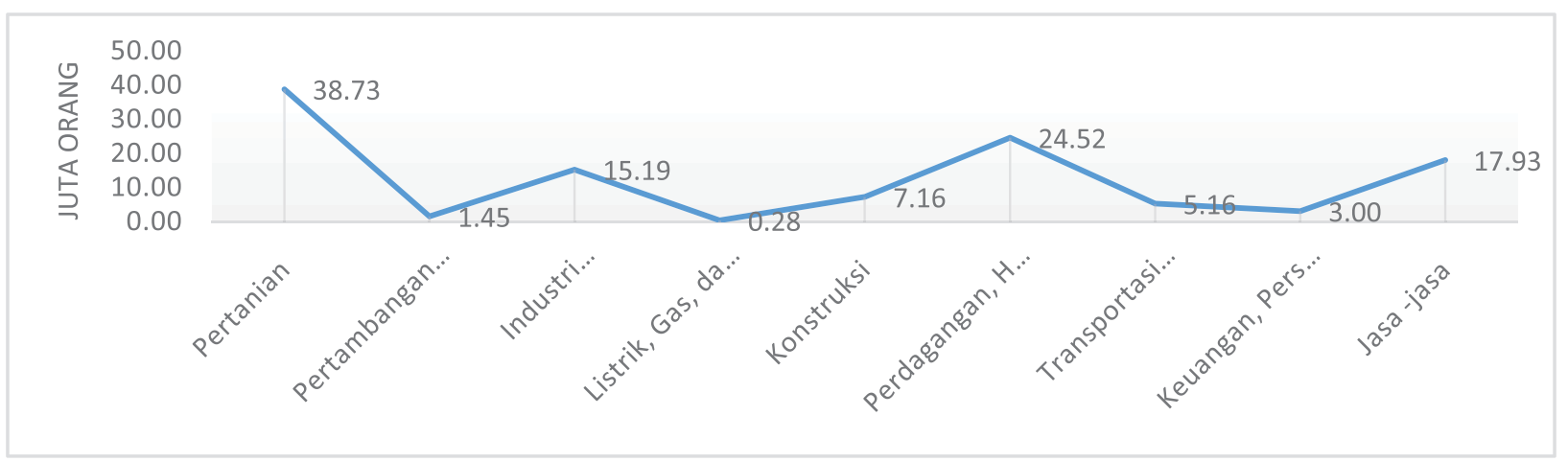

Sumber: BPS-RI, 2018 (diolah)

Berdasarkan Sensus Pertanian 2013, sektor pertanian yang menyerap tenaga kerja paling banyak di Indonesia adalah subsektor tanaman pangan. Jumlah tenaga kerja yang bekerja di sektor pertanian sebanyak 31.705.337 orang dan dari jumlah tersebut yang bekerja di subsektor tanaman pangan adalah sebanyak 20.399 .139 orang (64,34 persen). Hal ini menunjukkan pentingnya peranan subsektor tanaman pangan dalam menyerap tenaga kerja. Secara rinci pada Tabel 1.

Kegiatan ekonomi yang berbasis pada tanaman pangan merupakan kegiatan yang sangat penting (strategis) di Indonesia. Hal ini terjadi karena komoditas tanaman pangan menjadi bahan pangan pokok bagi sebagian besar masyarakat di Indonesia. Sebagai bahan pangan pokok, produk tanaman pangan, dan hortikultura menjadi faktor utama
Tabel 1. Jumlah Petani Menurut Subsektor di Indonesia

\begin{tabular}{lr}
\hline Subsektor & Jumlah Petani (Orang) \\
\hline Tanaman Pangan & 20.399 .139 \\
Hortikulura & 11.950 .989 \\
Perkebunan & 14.116 .465 \\
Peternakan & 14.738 .289 \\
Perikanan & 2.216 .119 \\
Kehutanan & 7.249 .030 \\
\hline Sektor Pertanian* & 31.705 .337 \\
\hline
\end{tabular}

Sumber: Laporan Hasil Sensus Pertanian 2013, BPS

Ket : Satu orang petani dapat mengusahakan lebih dari 1 subsektor usaha pertanian, sehingga secara keseluruhan di Sektor Pertanian bukan merupakan penjumlahan petani dari masingmasing subsektor

rawan pangan dan gizi, meningkatkan nilai tambah dan daya saing komoditas pangan 
di pasar dalam negeri dan luar negeri, meningkatkan pengetahuan dan kesadaran masyarakat tentang pangan yang aman, bermutu, dan bergizi bagi konsumsi masyarakat. Tujuan penting lainnya juga meningkatkan kesejahteraan bagi petani, nelayan, pembudi daya ikan, dan pelaku usaha pangan, serta melindungi dan mengembangkan kekayaan sumber daya pangan nasional.

Terkait daya saing, Coronado, dkk. (2017) telah mengidentifikasi bahwa potensi sumber daya alam yang memengaruhi produktivitas pertanian di Peru dengan penggunaan air, tanah, produksi, pendapatan, dan jumlah penduduk pedesaan menentukan daya saing suatu daerah/wilayah. Penelitian terkait daya saing komoditas tanaman pangan sudah dilakukan oleh beberapa peneliti, diantaranya Nurmalina (2008) menyebutkan bahwa terdapat tujuh faktor dominan yang sangat berpengaruh dalam sistem ketersediaan beras yaitu produksi, produktivitas, konversi lahan, pencetakan sawah, kesesuaian lahan, konsumsi per kapita, dan jumlah penduduk. Lebih lanjut Azahari dan Hadiutomo (2013) menyebutkan beras Indonesia mempunyai daya saing yang sangat rendah dan terus mengalami penurunan daya saing dari tahun ke tahun serta tidak mempunyai daya saing di pasar dunia. Hasil kajian yang dilakukan oleh Suryana dan Agustian (2014) menunjukkan bahwa usaha tani jagung di Indonesia menguntungkan secara finansial dan ekonomi serta secara nasional juga memiliki daya saing kuat. Hasil penelitian kedelai di tiga agroekosistem yang berbedayaitu di lahan sawah irigasi, sawah tadah hujan, dan lahan tegalan di 3 Provinsi yaitu Jawa Barat, Jawa Timur, dan
Sulawesi Selatan menunjukkan bahwa usaha tani kedelai di tiga agroekosistem tersebut cukup efisien dan keunggulan kompetitifnya cukup memadai sebagai substitusi impor (Sarwono dan Pratama, 2014). Pengembangan kedelai di wilayah Afrika Sub Sahara yang didominasi oleh negara-negara miskin juga cukup menjanjikan (Khojely, dkk., 2017). Menurut penelitian Asnawi dan Mejaya (2016) yang dilakukan di Kabupaten Lampung Tengah, ubi kayu lebih menguntungkan untuk diusahakan dengan nilai $\mathrm{R} / \mathrm{C}$ tertinggi dibandingkan jagung dan kedelai.

Kabupaten Sukoharjo merupakan salah satu kabupaten penyangga pangan di Jawa Tengah. Menurut BPS, tahun 2016 produktivitas padi mencapai $72,08 \mathrm{kuintal} / \mathrm{ha}$ dan menjadi yang tertinggi di Jawa Tengah dengan produksi mencapai 391.675 ton. Selain padi, komoditas tanaman pangan lain yang diusahakan di Kabupaten Sukoharjo yaitu jagung, kedelai, kacang tanah, kacang hijau, ubikayu, dan ubijalar. Diantara komoditas tanaman pangan, padi merupakan komoditi dengan produksi paling tinggi sedangkan ubijalar paling rendah seperti pada Tabel 2.

Luas panen komoditas tanaman pangan di Kabupaten Sukoharjo berfluktuatif dan pada tahun 2012 mengalami peningkatan yang signifikan yang disumbang oleh luas panen padi. Luas panen komoditas tanaman pangan tahun 2013-2015 cenderung stabil dan masih didominasi oleh padi seperti pada Gambar 2.

Adanya persaingan lahan antar komoditas tanaman pangan maupun dengan komoditas subsektor pertanian lain mendorong pemerintah

Tabel 2. Produksi Komoditas Tanaman Pangan di Kabupaten Sukoharjo (Ton), 2011-2015

\begin{tabular}{lrrrrr}
\hline \multirow{2}{*}{ Komoditas } & \multicolumn{5}{c}{ Produksi (Ton) } \\
\cline { 2 - 5 } & $\mathbf{2 0 1 1}$ & $\mathbf{2 0 1 2}$ & $\mathbf{2 0 1 3}$ & $\mathbf{2 0 1 4}$ & $\mathbf{2 0 1 5}$ \\
\hline Padi & 190.411 & 346.039 & 328.967 & 310.276 & 374.546 \\
Jagung & 28.609 & 23.901 & 21.424 & 18.498 & 22.056 \\
Kedelai & 4.325 & 4.312 & 3.523 & 3.005 & 3.950 \\
Kc. Tanah & 12.548 & 12.942 & 7.980 & 11.456 & 8.177 \\
Kc. Hijau & 148 & 140 & 61 & 40 & 23 \\
Ubikayu & 40.396 & 36.190 & 36.868 & 27.864 & 31.418 \\
Ubijalar & 12 & 13 & 12 & 173 & - \\
\hline
\end{tabular}

Sumber: Sukoharjo dalam Angka 2018, diolah 




Gambar 2. Luas Panen Komoditas Tanaman Pangan di Kabupaten Sukoharjo Tahun 2011-2015

daerah untuk memprioritaskan komoditas yang menjadi unggulan. Selain itu dalam menentukan komoditas prioritas juga harus mempertimbangkan dampak pengembangan komoditas tersebut terhadap pendapatan dan kesejahteraan petani. Mulyono dan Munibah (2016) telah melakukan analisis penentuan komoditas tanaman pangan unggulan di Kabupaten Bantul dengan menggunakan analisis Location Quotient (LQ), Shift Share Analysis (SSA), dan Zona Agroekologi (ZAE). Selanjutnya Keratorop, dkk. (2016) telah melakukan penelitian untuk mengkaji arahan pengembangan komoditas tanaman pangan di Kabupaten Boven Digoel Provinsi Papua dengan menggunakan analisis Location Quotient (LQ), Shift Share Analysis (SSA), dan Delinasi Lahan tersedia. Berdasarkan uraian di atas, perlu kiranya dilakukan analisis terkait peranan komoditas tanaman pangan unggulan di Kabupaten Sukoharjo dengan menggunakan analisis Location Quotient (LQ), Shift Share Analysis (SSA), dan Analisis Input Output (angka pengganda/multiplier effect pendapatan dan kesempatan kerja) untuk menentukan komoditas tanaman pangan unggulan yang memiliki multiplier effect yang besar terhadap pendapatan dan kesempatan kerja.

\section{METODOLOGI}

Penelitian ini menggunakan metode deskriptif analitis dengan alat analisis Location Quotient (LQ), Shift Share Analysis (SSA), dan Input-Output (IO). Penentuan lokasi penelitian dilakukan secara sengaja (purposive), yaitu di wilayah Kabupaten Sukoharjo dimana sektor pertaniannya memiliki kontribusi terkecil dibandingkan kabupaten lain di wilayah Solo
Raya. Jenis data yang digunakan dalam penelitian ini adalah data sekunder yaitu data produksi komoditas tanaman pangan tahun 2011-2015 di Kabupaten Sukoharjo dan Jawa Tengah, Tabel Input-Output Kabupaten Sukoharjo Tahun 2012: Transaksi Total Atas Dasar Harga Produsen (Juta Rupiah) Klasifikasi 33 Sektor, dan data penduduk usia 15 tahun ke atas yang bekerja menurut lapangan usaha utama di Kabupaten Sukoharjo tahun 2012. Data tersebut bersumber dari Bapeda Kabupaten Sukoharjo, BPS Kabupaten Sukoharjo, dan BPS Provinsi Jawa Tengah.

\subsection{Location Quotient (LQ)}

LQ digunakanuntukmengetahui konsentrasi dan/atau penyebaran aktivitas produksi di suatu wilayah dan menggambarkan keunggulan komparatif memproduksi suatu komoditas di suatu wilayah (Saragih, 2015).

Rumusan LQ yang digunakan dalam penentuan sektor basis dan non basis dinyatakan dengan persamaan (Widodo, 2006):

$\mathrm{LQ}=\frac{\mathrm{Vij} / \mathrm{Vj}}{\mathrm{Vin} / \mathrm{Vn}}$

Keterangan :

$\mathrm{LQ}=$ Koefisien Location Quotient (LQ)

$\mathrm{V}_{\mathrm{ij}}=$ Produksi komoditas $\mathrm{i}$ di wilayah $\mathrm{j}$

$\mathrm{V}_{\mathrm{j}} \quad=$ Produksi total komoditas tanaman pangan di wilayah j

$\mathrm{V}_{\text {in }}=$ Produksi komoditas i di wilayah referensi

$\mathrm{V}_{\mathrm{n}}=$ Produksi total komoditas tanaman pangan di total wilayah referensi

Apabila hasil perhitungan menunjukkan:

LQ > 1 berarti komoditas tersebut merupakan 
komoditas basis (wilayah j lebih berspesialisasi dalam memproduksi komoditas $i$ dibandingkan wilayah referensi).

LQ < 1 berarti komoditas tersebut merupakan komoditas non basis (wilayah j tidak berspesialisasi dalam memproduksi komoditasidibandingkan wilayah referensi).

$\mathrm{LQ}=1$ berarti baik wilayah $\mathrm{j}$ maupun wilayah referensi sama derajat spesialisasinya dalam memproduksi komoditas $i$.

\subsection{Shift-Share Analysis (SSA)}

SSA digunakan untuk mengetahui perubahan dan pergeseran struktur ekonomi wilayah j dikaitkan dengan perekonomian daerah yang menjadi referensi. Analisis shift share digunakan dengan pendekatan yang menggabungkan dua hal pokok yaitu unsur spasial dan unsur sektoral yang diterapkan dalam kerangka dimensi waktu. Ketiga komponen pertumbuhan secara matematik dapat dinyatakan sebagai berikut (Budiharsono, 2005):

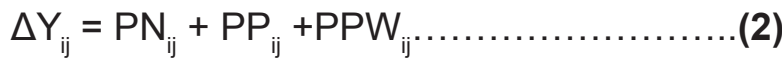

$$
\begin{aligned}
& P N_{i j}=Y_{i j}(R a-1) \text {. } \\
& P P_{i j}=Y_{i j}(R i-R a) \text {. } \\
& P P W_{i j}=Y_{i j}(r i-R i) \\
& \text { dan } r_{i} \quad=Y^{\prime} / Y_{i j} \\
& \mathrm{R}_{\mathrm{i}} \quad=\mathrm{Y}^{\prime} / \mathrm{Y}_{\mathrm{i}} \\
& \Delta Y_{i j}=\text { Total Komponen Pertumbuhan } \\
& \mathrm{PN}_{\mathrm{ij}} \quad=\text { Komponen Pertumbuhan Nasional } \\
& \mathrm{PP}_{\mathrm{ij}} \quad=\text { Komponen Pertumbuhan Proporsional } \\
& \mathrm{PPW}_{\mathrm{ij}}=\begin{array}{l}
\text { Komponen Pertumbuhan Pangsa } \\
\text { Wilayah }
\end{array}
\end{aligned}
$$

Keterangan:

$$
\begin{aligned}
\Delta Y_{i j}= & \begin{array}{l}
\text { Komponen pertumbuhan komoditas } \mathrm{i} \\
\text { di wilayah } \mathrm{j}
\end{array} \\
Y_{\mathrm{ij}}= & \begin{array}{l}
\text { Produksi komoditas } \mathrm{i} \text { wilayah } \mathrm{j} \text { pada } \\
\text { tahun dasar analisis }
\end{array} \\
Y_{i j}^{\prime}= & \begin{array}{l}
\text { Produksi komoditas } \mathrm{i} \text { wilayah } \mathrm{j} \text { pada } \\
\text { tahun akhir analisis }
\end{array} \\
Y_{\mathrm{i}}= & \begin{array}{l}
\text { Produksi komoditas } \mathrm{i} \text { wilayah } \\
\text { referensi pada tahun dasar analisis }
\end{array}
\end{aligned}
$$

$$
\begin{aligned}
Y_{1}^{\prime}= & \begin{array}{l}
\text { Produksi komoditas i wilayah } \\
\text { referensi pada tahun akhir analisis }
\end{array} \\
Y^{\prime}= & \begin{array}{l}
\text { Produksi total komoditas tanaman } \\
\text { pangan wilayah referensi pada tahun } \\
\text { dasar analisis }
\end{array} \\
Y^{\prime}= & \begin{array}{l}
\text { Produksi total komoditas tanaman } \\
\text { pangan wilayah referensi pada tahun } \\
\text { akhir analisis }
\end{array}
\end{aligned}
$$

Kriteria:

Pertama, apabila $\mathrm{PP}_{\mathrm{ij}}>0$ (menunjukkan bahwa komodits i pada wilayah ke-j pertumbuhannya cepat); $\mathrm{PP}_{\mathrm{ij}}<0$ ( menunjukkan bahwa komoditas i pada wilayah ke-j pertumbuhannya lambat).

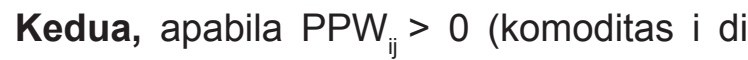
di wilayah i mempunyai daya saing yang baik apabila dibandingkan dengan wilayah referensi)


di wilayah j tidak memiliki daya saing apabila dibandingkan dengan wilayah referensi).

\subsection{Analisis Angka Pengganda (Multiplier Effect)}

Analisis angka pengganda dapat menjelaskan dampak yang terjadi terhadap variabelvariabel ekonomi seperti produksi, kesempatan kerja atau pendapatan regional apabila terjadi perubahan variabel-variabel eksogen, seperti permintaan akhir (Widodo, 2006). Analisis angka pengganda yang dilakukan meliputi:

\subsubsection{Analisis Angka Pengganda Output}

Angka pengganda output (suatu sektor) adalah nilai total dari output yang dihasilkan oleh perekonomian untuk memenuhi (atau akibat) adanya perubahan satu unit uang permintaan akhir dari sektor tersebut (Kuncoro, 2010). Adanya peningkatan permintaan akhir (final demand) pada suatu sektor akan meningkatkan output sektor itu sendiri dan sektor-sektor lain dalam perekonomian. Peningkatan output sektor-sektor lain ini tercipta akibat adanya efek langsung dan tidak langsung (hubungan teknis antar sektor) dari peningkatan permintaan akhir. Besarnya angka pengganda output untuk sektor ke-n di dalam perekonomian dihitung dari penjumlahan kolom ke-n dari matriks Kebalikan Leontif untuk perekonomian yang bersangkutan. Angka Pengganda Output sektor ke j dapat dinotasikan dengan $\mathrm{O}_{j}$ dan dirumuskan sebagai 
berikut (Widodo, 2006):

$\mathrm{O}_{j}=\sum_{\mathrm{i}=1}^{\mathrm{n}} \alpha \mathrm{ij}$

Keterangan :

$\alpha_{i j}=$ elemen matriks kebalikan Leontif

\subsubsection{Analisis Angka Pengganda Pendapatan}

Angka pengganda pendapatan rumah tangga suatu sektor menunjukkan jumlah pendapatan rumah tangga total yang tercipta akibat adanya tambahan satu unit permintaan akhir di sektor tersebut (Kuncoro, 2010). Jika terdapat perubahan permintaan akhir, terjadi pula perubahan output yang diproduksi oleh setiap sektor produksi yang terkait di perekonomian. Hal ini ditunjukkan oleh angka pengganda output. Perubahan jumlah output yang diproduksi tersebut tentunya akan pula mengubah permintaan tenaga kerja yang dibutuhkan. Karena balas jasa tenaga kerja tersebut merupakan sumber pendapatan rumah tangga (upah), maka perubahan permintaan kerja akan mempengaruhi pendapatan rumah tangga. Hubungan antara total output setiap sektor dengan balas jasa tenaga kerja tersebut ditunjukkan oleh baris ke $(n+1)$ dari matriks input output tersebut (yang tidak lain adalah komponen upah dan gaji di matriks input primer). Biasanya hal ini disebut sebagai koefisien upah dan gaji yang besarnya adalah rasio antara nilai upah dan gaji dengan nilai total inputnya. Angka pengganda pendapatan diperoleh dari perkalian antara koefisien pendapatan dengan angka pengganda output. Angka pengganda pendapatan sektor j dapat dinotasikan dengan $\mathrm{H}_{\text {}}$ dan dirumuskan sebagai berikut (Widodo, 2006):

$\mathrm{Hj}=\sum_{i=1}^{n} \mathrm{a}_{n+1}, \alpha \mathrm{ij}$

Keterangan:

aij = unsur matriks kebalikan Leontif

\subsubsection{Analisis Angka Pengganda Kesempatan Kerja}

Angka pengganda kesempatan kerja adalah efek total dari perubahan lapangan kerja di perekonomian akibat adanya satu unit uang perubahan permintaan akhir di suatu sektor (Kuncoro, 2010). Akibat adanya peningkatan produksi akan meningkatkan permintaan tenaga kerja. Untuk dapat menangkap efek dari satu unit perubahan permintaan akhir di suatu sektor produksi terhadap perubahan lapangan pekerjaan di seluruh perekonomian, diperlukan jumlah lapangan pekerjaan awal, atau jumlah tenaga kerja awal pada masing-masing sektor produksi yang memang telah digunakan untuk melakukan proses produksi. Data tersebut digunakan untuk menghitung berapa kontribusi setiap pekerja, secara rata-rata, dalam memproduksi output sektornya masing-masing. Jika nilai rata-rata output setiap pekerja di sektor j dinotasikan $\mathrm{W}_{\mathrm{j}}$ maka diperoleh :

$W_{j}=\frac{X_{j}}{L_{j}}$.

Keterangan:

$L_{j}=$ jumlah pekerja di sektor $j$

$\mathrm{X}_{\mathrm{j}}=$ total output di sektor $\mathrm{j}$

Tambahan permintaan akhir di sektor j akan menyebabkan tambahan output tidak saja di sektor j, tetapi juga tambahan output di sektor i. Pada gilirannya, tambahan output di sektor $\mathrm{j}$ tadi akan meningkatkan permintaan tenaga kerja untuk sektor j tersebut. Sedangkan tambahan output di sektor i, akibat tambahan permintaan akhir di sektor $\mathrm{j}$ tadi, akan meningkatkan tenaga kerja di sektor i pula. Oleh karena itu, efek lapangan pekerjaan dari penambahan atau perubahan satu unit output di sektor $\mathrm{j}$ adalah sebesar angka pengganda kesempatan kerja sektor j. Angka pengganda kesempatan kerja didapatkan dari perkalian koefisien tenaga kerja dengan angka pengganda outputnya dimana koefisien tenaga kerja merupakan rasio antara jumlah tenaga kerja sektoral dengan total inputnya. Angka pengganda kesempatan kerja sektor $\mathrm{j}$ dapat dinotasikan dengan $\mathrm{E}_{\mathrm{j}}$ dan dirumuskan sebagai berikut (Widodo, 2006):

$\mathrm{Ej}=\sum_{i=1}^{n} \mathrm{~W}_{n+1}, \alpha \mathrm{ij}$

Keterangan :

aij = unsur matriks kebalikan Leontif

\section{HASIL DAN PEMBAHASAN}

\subsection{Analisis Location Quotient (LQ)}

Perhitungan analisis LQ menggunakan perbandingan data produksi komoditas tanaman pangan (padi, jagung, kedelai, kacang tanah, kacang hijau, ubikayu, dan ubijalar) di Kabupaten Sukoharjo dengan Jawa Tengah. 
Tabel 3. Nilai LQ Komoditas Pangan di Kabupaten Sukoharjo

\begin{tabular}{lcccccc}
\hline \multirow{2}{*}{ Komoditi } & \multicolumn{6}{c}{ Rata-rata Nilai LQ Komoditas Pangan di Kabupaten Sukoharjo } \\
\cline { 2 - 7 } & $\mathbf{2 0 1 1}$ & $\mathbf{2 0 1 2}$ & $\mathbf{2 0 1 3}$ & $\mathbf{2 0 1 4}$ & $\mathbf{2 0 1 5}$ & $\mathbf{2 0 1 6}$ \\
\hline Padi & 1,19 & 1,41 & 1,42 & 1,49 & 1,40 & 1,38 \\
Jagung & 0,60 & 0,33 & 0,33 & 0,28 & 0,29 & 0,37 \\
Kedelai & 2,25 & 1,18 & 1,59 & 1,11 & 1,28 & 1,48 \\
Kc. Tanah & 6,00 & 3,76 & 2,79 & 4,42 & 3,16 & 4,03 \\
Kc. Hijau & 0,07 & 0,05 & 0,04 & 0,02 & 0,01 & 0,04 \\
Ubikayu & 0,68 & 0,39 & 0,40 & 0,32 & 0,37 & 0,43 \\
Ubijalar & 0,00 & 0,00 & 0,00 & 0,04 & - & 0,01 \\
\hline
\end{tabular}

Sumber: Hasil Analisis, 2018

Hasil perhitungan LQ menunjukkan komoditas yang mempunyai produksi berlebih atau sebagai komoditas unggulan di Kabupaten Sukoharjo. Komoditas dengan nilai $L Q>1$ menunjukkan bahwa komoditas tersebut merupakan komoditi basis, artinya produksi yang dihasilkan mampu untuk memenuhi kebutuhan daerah tersebut, bahkan mampu mengekspor ke luar wilayah. Sebaliknya komoditi non basis hasil produksinya belum mampu memenuhi permintaan dalam wilayah tersebut sehingga harus mengimpor dari luar wilayah.

Nilai LQ pada Tabel 3 menunjukkan pada subsektor tanaman pangan terdapat tiga (3) komoditi yang menjadi komoditas basis di Kabupaten Sukoharjo yaitu padi, kedelai, dan kacang tanah. Komoditas tanaman pangan yang memiliki nilai LQ tertinggi yaitu kacang tanah dengan nilai $L Q$ sebesar 4,03 artinya satu bagian untuk memenuhi permintaan di wilayah Kabupaten Sukoharjo sedangkan sisanya yaitu 3,03 bagian untuk memenuhi permintaan dari luar wilayah kabupaten Sukoharjo (ekspor). Komoditas kedua yang menjadi basis yaitu kedelai, hal ini sesuai dengan penelitian Barokah (2011) bahwa Kabupaten Sukoharjo merupakan salah satu sentra kedelai di Jawa Tengah selain Kabupaten Grobogan dan Wonogiri dimana petani kedelainya mengusahakan lahan ratarata 0,057 ha. Padi merupakan komoditi basis ketiga dengan nilai LQ sebesar 1,38, artinya dari produksi padi yang dihasilkan di Kabupaten Sukoharjo, satu (1) bagian untuk memenuhi permintaan di dalam wilayah sedangkan sisanya sebanyak 0,38 bagian diekspor keluar wilayah. Meskipun luas wilayah Kabupaten Sukoharjo terkecil kedua di Jawa Tengah, tetapi produktivitas padi tertinggi sehingga menjadi

Tabel 4. Analisis Shift Share Komoditas Tanaman Pangan di Kabupaten Sukoharjo, 2011 dan 2015

\begin{tabular}{lrrrr}
\hline \multirow{2}{*}{ Komoditi } & \multicolumn{4}{c}{ Komponen } \\
\cline { 2 - 5 } & PNij (ton) & PPij (ton) & $\begin{array}{c}\text { PPWij } \\
\text { (ton) }\end{array}$ & \multicolumn{1}{c}{$\Delta$ Yij (ton) } \\
\hline Padi & 28.248 & 10.464 & 145.423 & 184.135 \\
Jagung & 4.244 & 294 & $(11.091)$ & $(6.553)$ \\
Kedelai & 642 & 33 & $(1.050)$ & $(375)$ \\
Kc. Tanah & 1.862 & $(3.206)$ & $(3.027)$ & $(4.371)$ \\
Kc. Hijau & 22 & $(44)$ & $(103)$ & $(125)$ \\
Ubikayu & 5.993 & $(5.184)$ & $(9.787)$ & $(8.978)$ \\
Ubijalar & 2 & $(2)$ & $(11)$ & $(12)$ \\
Jumlah & 41.013 & 2.355 & 120.354 & 163.722 \\
\hline \multicolumn{1}{c}{$(\%)$} & 25,05 & 1,44 & 73,51 & 100,00 \\
\hline
\end{tabular}

Sumber: Hasil Analisis, 2018

*) Angka dalam kurung menyatakan nilai negatif

Keterangan :

PNij = Komponen Pertumbuhan Nasional Komoditas i di Kabupaten Sukoharjo

$\mathrm{PPij}=$ Komponen Pertumbuhan Proporsional Komoditas i di Kabupaten Sukoharjo

PPWij = Komponen Pertumbuhan Pangsa Wilayah Komoditas i di Kabupaten Sukoharjo

$\Delta Y_{i j}=$ Total Komponen Pertumbuhan 
salah satu kabupaten penyangga pangan Jawa Tengah (BPS, 2018).

Sebagai komoditas basis, tanaman kedelai, kacang tanah, dan padi di Kabupaten Sukoharjo diharapkan mampu mendorong perkembangan komoditas non basis. Produksi yang berlebih yang dipasarkan di luar wilayah Kabupaten Sukoharjo merupakan sumber pendapatan bagi rumah tangga petani, yang digunakan untuk konsumsi dan sebagian lagi untuk modal usahatani. Dengan tersedianya modal, petani dapat mengakses saprodi (pupuk, benih/ bibit unggul, membayar sewa lahan) untuk memproduksi baik komoditas basis maupun non basis. Hal yang harus diperhatikan dalam pengembangan komoditas basis adalah kemampuan pasar di luar wilayah tersebut dalam menampung komoditas basis tersebut.

\subsection{Analisis Shift Share (SSA)}

Perhitungan analisis Shift Share diperoleh dari data produksi tanaman pangan (padi, jagung, kedelai, kacang tanah, kacang hijau, ubikayu, dan ubijalar) Kabupaten Sukoharjo dibandingkan dengan data produksi komoditas yang sama Jawa Tengah tahun 2011 dan 2015. Dengan demikian dapat dilihat pertumbuhan atau penurunan produksi pada komoditas tanaman pangan.

Hasil analisis Shift Share pada Tabel 4 menunjukkan bahwa komoditas tanaman pangan yang mempunyai nilai komponen Pertumbuhan Proporsional (PPij) positif yaitu padi, jagung, dan kedelai, artinya pertumbuhan ketiga komoditas ini lebih cepat dibandingkan komoditas yang sama di Jawa Tengah. Komoditas tanaman pangan yang mempunyai daya saing hanya komoditi padi yang ditunjukkan dengan nilai Pertumbuhan Pangsa Wilayah (PPWij) $>0$ atau bernilai positif. Daya saing komoditas padi di Kabupaten Sukoharjo dipengaruhi oleh sarana prasarana pendukung diantaranya jaringan irigasi. Menurut data BPS (2018), sekitar 70 persen lahan sawah di Kabupaten Sukoharjo sudah beririgasi teknis sehingga mempengaruhi IP padi. Hal ini sesuai dengan hasil penelitian Coronado dkk. (2017) bahwa ketersediaan air mempengaruhi daya saing pertanian.

Permasalahan utama yang dihadapi dalam pembangunan pertanian khususnya tanaman
Tabel 5. Nilai Angka Pengganda Output Komoditas Tanaman Pangan di Kabupaten Sukoharjo

\begin{tabular}{llcc}
\hline No. & Sektor & $\begin{array}{c}\text { Output } \\
\text { Multiplier }\end{array}$ & Rank \\
\hline 1 & Padi & 1,2070 & 3 \\
2 & Jagung & 1,2448 & 1 \\
3 & Ketela Pohon & 1,1011 & 5 \\
4 & Kacang-Kacangan & 1,2130 & 2 \\
5 & Bahan Makanan & 1,1605 & 4 \\
& Lainnya & & \\
\hline
\end{tabular}

Sumber: Tabel Input-Output Kabupaten Sukoharjo Tahun 2012 Klasifikasi 33 Sektor, diolah

pangan di Kabupaten Sukoharjo adalah adanya alih fungsi lahan pertanian produktif ke non pertanian, dimana pada periode 2011-2015 telah terjadi penurunan luas baku lahan sawah sebesar 2 persen. Hal ini perlu mendapatkan perhatian khusus dari pemerintah daerah, karena akan berpengaruh terhadap produksi komoditas pangan bahkan dalam jangka panjang akan berpengaruh terhadap ketahanan pangan. Hal ini sesuai dengan penelitian Wijaya (2017) bahwa konversi lahan pertanian ke non pertanian merupakan ancaman dalam pengembangan komoditas pangan unggulan. Menurut penelitian Sutomo dan Istiqomah (2015), alih fungsi lahan berpengaruh terhadap tingkat ketahanan pangan rumah tangga petani di Kabupaten Karanganyar. Rumah tangga petani yang tidak melakukan alih fungsi lahan memiliki peluang yang lebih besar untuk akses pangan. Menurut Fagi (2013) alih fungsi lahan produktif menyebabkan ketidakseimbangan antara suplly dan demand, serta ketergantungan terhadap pangan impor akan semakin besar sehingga alih fungsi lahan harus diatasi dengan reformasi agraria (Sucihatiningsih, 2014) agar ada proporsi yang ideal antara lahan untuk subsektor tanaman pangan dan lahan untuk sektor/subsektor lain. Selain alih fungsi lahan, penguasaan lahan yang sempit juga menjadi masalah dalam pembangunan pertanian (Nainggolan, 2008; Bantacut, 2014).

\subsection{Analisis Multiplier (Angka Pengganda)}

Analisis angka pengganda (multiplier analysis) mencoba melihat apa yang terjadi terhadap variabel-variabel endogen apabila terjadi perubahan variabel eksogen, seperti permintaan akhir (final demand) di dalam 
perekonomian (Nazara, 2005). Komponen permintaan akhir meliputi konsumsi rumah tangga, pengeluaran pemerintah, investasi atau pembentukan modal tetap, perubahan stok, dan ekspor. Variabel yang menjadi perhatian dalam analisis angka pengganda adalah output, pendapatan rumah tangga dan lapangan pekerjaan. Adanya permintaan akhir terhadap suatu sektor akan menyebabkan kenaikan output, dengan adanya kenaikan output maka permintaan tenaga kerja akan meningkat yang diikuti oleh kenaikan pendapatan. Menurut Puspita (2015) kenaikan output akan menyebabkan terserapnya tenaga kerja yang diikuti dengan kenaikan PDRB dan penurunan kemiskinan.

Hasil analisis angka pengganda output pada Tabel 5 menunjukkan bahwa jagung memiliki angka pengganda output tertinggi yaitu sebesar 1,2448, artinya setiap kenaikan satu (1) unit rupiah permintaan akhir terhadap jagung akan meningkatkan output total perekonomian sebesar 1,2448 unit rupiah. Komoditas tanaman pangan yang memiliki angka pengganda output terkecil yaitu ubikayu (ketela pohon) dengan nilai angka pengganda output sebesar 1,1011. Padi yang merupakan komoditas unggulan memiliki angka pengganda output peringkat ketiga dengan nilai sebesar 1,2070. Permintaan akhir terhadap padi tidak hanya akan meningkatkan output padi tersebut, tetapi juga akan meningkatkan output sektor-sektor lain dalam perekonomian. Sektor atau subsektor yang memiliki keterkaitan tinggi dengan padi adalah sektor padi sendiri yaitu sebagai benih, sektor peternakan dimana jerami padi digunakan sebagai pakan, industri penggilingan padi, industri makanan, dan perdagangan.

Tabel 6. Angka Pengganda Pendapatan Komoditas Tanaman Pangan di Kabupaten Sukoharjo

\begin{tabular}{clcc}
\hline No. & Sektor & $\begin{array}{c}\text { Income } \\
\text { Multiplier }\end{array}$ & Rank \\
\hline 1 & Padi & 0,0325 & 1 \\
2 & Jagung & 0,0198 & 3 \\
3 & Ubikayu & 0,0058 & 5 \\
4 & Kacang-Kacangan & 0,0102 & 4 \\
5 & Bahan Makanan & 0,0252 & 2 \\
& Lainnya & & \\
\hline
\end{tabular}

Sumber: Tabel Input-Output Kabupaten Sukoharjo Tahun 2012 Klasifikasi 33 Sektor, diolah
Sektor jagung memiliki keterkaitan yang tinggi dengan sektor peternakan, industri makanan, dan industri pakan.

Berdasarkan hasil analisis angka pengganda pendapatan rumah tangga pada Tabel 6 menunjukkan bahwa padi memiliki angka pengganda pendapatan tertinggi yaitu 0,0325 artinyasetiapkenaikansatuunitrupiah permintaan akhir (final demand) terhadap sektor padi akan meningkatkan pendapatan rumah tangga total sebesar 0,0325 unit rupiah. Berdasarkan koefisien upah, padi memiliki koefisien tertinggi dibandingkan komoditas tanaman pangan yang lain. Sekitar 2,69 persen dari total output padi digunakan untuk membayar jasa tenaga kerja. Sebaliknya ubikayu memiliki angka pengganda pendapatan terendah yaitu sebesar 0,0058, artinya setiap kenaikan satu (1) unit rupiah permintaan akhir terhadap sektor ubikayu hanya akan meningkatkan pendapatan rumah tangga total sebesar 0,0058 unit rupiah. Hal ini berbeda dengan hasil penelitian Asnawi dan Mejaya (2016) yang dilakukan di Kabupaten Lampung Tengah, dimana ubi kayu lebih menguntungkan untuk diusahakan dibandingkan jagung dan kedelai. Hal ini disebabkan karena harga jual ubikayu di Lampung Tengah relatif tinggi, mudah diusahakan, produksi tinggi, mudah dalam penjualan, dan memiliki resiko kegagalan panen lebih rendah dibandingkan dengan usahatani jagung dan kedelai. Lebih lanjut hasil penelitian Ullah dan Routray (2007) menyebutkan bahwa pendapatan rumah tangga ditentukan oleh luas kepemilikan lahan, tenaga kerja anggota keluarga, morbiditas, dan kesempatan kerja.

Padi memiliki keterkaitan yang kuat dengan sektor hilirnya yaitu sebagai penyedia bahan

Tabel 7. Angka Pengganda Kesempatan Kerja Komoditas Tanaman Pangan di Kabupaten Sukoharjo

\begin{tabular}{llcc}
\hline No & \multicolumn{1}{c}{ Sektor } & $\begin{array}{c}\text { Employment } \\
\text { Multiplier }\end{array}$ & Rank \\
\hline 1 & Padi & 0,0275 & 3 \\
2 & Jagung & 0,0283 & 1 \\
3 & Ubikayu & 0,0251 & 5 \\
4 & Kacang-Kacangan & 0,0276 & 2 \\
5 & Bahan Makanan & 0,0264 & 4 \\
& Lainnya & & \\
\hline
\end{tabular}

Sumber: Tabel Input-Output Kabupaten Sukoharjo Tahun 2012 Klasifikasi 33 Sektor, diolah 
baku bagi industri penggilingan padi. Menurut Susilawati, dkk. (2007) agroindustri makanan memberikan pemerataan pendapatan yang lebih baik dibandingkan industri non makanan sedangkan jagung memiliki keterkaitan yang kuat dengan industri hulunya terutama industri pupuk.

Berdasarkan hasilanalisis angka pengganda kesempatan kerja pada Tabel 7 jagung memiliki angka pengganda kesempatan kerja tertinggi yaitu sebesar 0,0283 , artinya setiap kenaikan satu unit rupiah permintaan akhir terhadap jagung akan meningkatkan kesempatan kerja total sebesar 0,0283 orang. Sebaliknya ubikayu memiliki angka pengganda kesempatan kerja terendah yaitu sebesar 0,0251 . Padi memiliki angka pengganda kesempatan kerja peringkat ketiga yaitu sebesar 0,0275. Hal ini berbeda dengan hasil penelitian Oktavia, dkk. (2016) bahwa padi memiliki angka pengganda tenaga kerja tertinggi di Jawa Timur. Sektor jagung memiliki nilai keterkaitan yang tinggi dengan industri pakan ternak yaitu sebagai penyedia bahan baku. Dengan berkembangnya industri pakan maka akan membuka kesempatan kerja dan mengurangi jumlah pengangguran. Tenaga kerja di sektor industri pakan tentu saja memerlukan keterampilan yang lebih dibandingkan tenaga kerja on farm (buruh tani). Aislabie dan Ip (1977) telah melakukan penelitian dengan menggunakan teknik inputoutput untuk menyusun perencanaan kebutuha tenaga kerja dengan memilah data tenaga kerja sesuai persyaratan yang dibutuhkan oleh sektor industri (terampil, semi terampil, dan tidak terampil).

Daya saing suatu komoditas dapat dilihat dari dua indikator yaitu keunggulan komparatif dan keunggulan kompetitif. Komoditas yang memiliki keunggulan komparatif dan kompetitif merupakan komoditas unggulan. Pengembangan komoditas unggulan belum tentu memiliki multiplier effect yang tinggi terhadap pendapatan dan kesempatan kerja padahal tujuan pembangunan pertanian bukan hanya mengejar produksi yang tinggi tetapi juga untuk meningkatkan kesejahteraan petani. Kesejahteraan petani dapat terwujud dengan cara peningkatan pendapatan dan ketersediaan lapangan kerja. Apabila pembangunan pertanian khususnya subsektor tanaman pangan diarahkan untuk meningkatkan pemerataan pembangunan (pendapatan) maka pemberian stimulus atau investasi diprioritaskan untuk pengembangan komoditas yang memiliki angka pengganda pendapatan tinggi. Sebaliknya apabila tujuan utama pembangunan tanaman pangan untuk menyerap tenaga kerja dan mengurangi pengangguran, maka investasi diprioritaskan untuk pengembangan komoditas yang memiliki angka pengganda kesempatan kerja tinggi.

\section{KESIMPULAN}

Padi, kedelai, dan kacang tanah merupakan komoditas basis di Kabupaten Sukoharjo. Komoditas yang tumbuh lebih cepat adalah padi, jagung, dan kedelai tetapi yang memiliki daya saing hanya padi sehingga menjadi komoditas unggulan di Kabupaten Sukoharjo. Berdasarkan analisis angka pengganda, padi memiliki angka pengganda pendapatan tertinggi dibandingkan komoditas pangan lainnya yaitu sebesar 0,0325 meskipun angka pengganda kesempatan kerja hanya peringkat ketiga. Komoditas tanaman pangan yang memiliki angka pengganda kesempatan kerja tertinggi adalah jagung.

Apabila tujuan utama dari pembangunan subsektor tanaman pangan di Kabupaten Sukoharjo adalah untuk pemerataan pembangunan (pendapatan) maka pengembangan komoditas padi harus diprioritaskan karena memiliki daya saing komparatif dan kompetitif serta nilai angka pengganda pendapatan tertinggi. Sebaliknya apabila tujuan utama dari pembangunan subsektor tanaman pangan adalah untuk memacu pertumbuhan ekonomi dan menyerap tenaga kerja sebanyak-banyaknya maka pengembangan komoditi jagung harus dipertimbangkan karena memiliki angka pengganda output dan kesempatan kerja tertinggi. Tetapi hal yang tak kalah penting dan harus diperhatikan dalam pengembangan komoditas tanaman pangan adalah potensi daerah yang bersangkutan.

\section{DAFTAR PUSTAKA}

Aislabie, C. J., dan Ip, P. C. 1977. Manpower Planning Using Input-output Techniques. Economic Analysis and Policy. Vol. 7 (2): 3-24. https://doi. org/10.1016/ S0313-5926 (77) 50021-5. 
Asnawi, R., dan Mejaya, M.J. 2016. Analisis Keunggulan Kompetitif Ubi Kayu terhadap Jagung dan Kedelai di Kabupaten Lampung Tengah. Jurnal Penelitian Pertanian Tanaman Pangan. Vol. 35 (3): 209-216. http://dx.doi. org/10.21082/jpptp.v35n3. 2016. : 209-215.

Azahari, D. H., dan Hadiutomo, K. 2013. Analisis Keunggulan Komparatif Beras Indonesia. Analisis kebijakan Pertanian. Vol. 11 (1): 61-73. http://dx.doi.org/10.21082/akp.v11n1. 2013.61-73.

Bantacut, T. 2014. Agenda Pembangunan Pertanian dan Ketahanan Pangan 2014-2019 (Agenda of Agricultural Development and Food Security 2014-2019). Jurnal Pangan. Vol. 23 (3): 278-295. http://www.jurnalpangan.com/index. php/pangan/article/view/98.

Barokah, U. 2011. Analisis Biaya dan Pendapatan Usaha Tani Kedelai di Kabupaten Sukoharjo. SEPA: Sosial Ekonomi Pertanian dan Agribisnis. Vol. 8(1): 9-13. http://agribisnis. uns.ac.id/category/jurnal-sepa/vol-8-no-1september-2011.

Badan Pusat Statistik (BPS). 2013. Laporan Hasil Sensus Pertanian 2013 (Pencacahan Lengkap). Jakarta: BPS.

Badan Pusat Statistik Kabupaten Sukoharjo (BPS). 2018. Sukoharjo dalam Angka 2018. Sukoharjo: BPS.

Budiharsono, S. 2005. Teknik Analisa Pembangunan Wilayah Pesisir dan Lautan. Jakarta: Pradnya Paramita.

Coronado, F., Aguila D., Charles, V., dan Dwyer, J. 2017. Measuring Regional Competitiveness through Agricultural Indices of Productivity: The Peruvian Case. World Journal of Entrepreneurship, Management and Sustainable Development. Vol. 13 (2): 78-95. https://doi. org/ 10.1108 /WJEMSD-06-2016-0031.

Fagi, A. M. 2013. Ketahanan Pangan Indonesia dalam Ancaman: Strategi dan Kebijakan Pemantapan dan Pengembangan. Analisis Kebijakan Pertanian. Vol.11 (1): 11-25. http:// dx.doi.org/10.21082/akp.v11n1. 2013. 11-25.

Giap Tan, K., Rao, K., dan Rajan, R. 2015. How Productive is the Agricultural Sector Across Indian states?.International Journal of Development Issues. Vol. 14 (3): 231-248. https://doi.org/10.1108/IJDI-01-2015 0007.

Keratorop, M., Widiatmaka, dan Suwardi. 2016. Arahan Pengembangan Komoditas Tanaman Pangan di Kabupaten Boven Digoel Provinsi Papua. Jurnal Pengelolaan Sumberdaya Alam dan Lingkungan. Vol. 6 (2): 141-150. http://journal.ipb.ac.id/index.php/jpsl/article/ view/12230/11203.

Khojely, D. M., Ibrahim, S. E., Sapeya, E., dan Han, T. 2017. History, Current Status, and Prospects of Soybean Production and Research in SubSaharan. The Crop Journal. Vol. 6: 226-235. https://doi.org/10.1016 /j.cj.2018.03.006.

Kuncoro, M. 2010. Masalah, Kebijakan, dan Politik Ekonomika Pembangunan. Jakarta: Erlangga.

Mulyono, J., dan Munibah, K. 2016. Pendekatan Location Quotient dan Shift Share Analysis dalam Penentuan Komoditas Unggulan Tanaman Pangan di Kabupaten Bantul. Informatika Pertanian. Vol. 25 (2): 221-230. http://ejurnal.litbang.pertanian.go.id/index.php/ IP/article/view/8569.

Nainggolan, K. 2008. Arah Kebijakan Penyediaan Pangan dalam Negeri. Jurnal Pangan. Vol. 17 (1): 79-91. http://www.jurnalpangan.com/index. php/pangan/article/view/203.

Nazara, S. 2005. Analisis Input-Output Edisi Kedua. Jakarta: Lembaga Penerbit Fakultas Ekonomi Universitas Indonesia.

Nurmalina, R. 2008. Analisis Indeks Dan Status Keberlanjutan Sistem Ketersediaan Beras Di Beberapa Wilayah Indonesia. Jurnal Agro Ekonomi. Vol. 26 (1): 47-79. http://dx.doi. org/10.21082/jae.v26n1.2008.47-79

Nurman. 2015. Strategi Pembangunan Daerah. Jakarta: PT Raja Grafindo Perkasa.

Oktavia, H.F., Hanani, N., dan Suhartini. 2016. Peran Sektor Pertanian dalam Pembangunan Ekonomi di Provinsi Jawa Timur (Pendekatan InputOutput). Jurnal Habitat. Vol. 27 (2): 72-84. http:// doi.org/ 10.21776/ub.habitat. 2016.027.2.9.

Puspita, D. W. 2015. Analisis Determinan Kemiskinan di Provinsi Jawa Tengah. JEJAK: : Journal of Economics and Policy. Vol 8 (1): 100-107. http:// doi:10.15294/jejak. V8i1. 3858.

Saragih, B. 2010. Agribisnis Paradigma Baru Pembangunan Ekonomi Berbasis Pertanian. Bogor: IPB Press.

Saragih, J. R. 2015. Perencanaan Wilayah dan Pengembangan Ekonomi Lokal Berbasis Pertanian (Teori dan Aplikasi). Yogyakarta: Pustaka Pelajar.

Sarwono dan Pratama, W. 2014. Analisis Daya Saing Kedelai Indonesia. JEJAK: Journal of Economics and Policy. Vol. 7 (2): 100-202. http://dx.doi. org/10.15294/jejak.v7i1. 3596.

Sucihatiningsih, D. W. P. 2014. Strategy for Controlling Agricultural Land Conversion of Paddy by Using Analytical Hierarchy Process in Central Java. Management of Environmental Quality: 
An International Journal. Vol. 25 (5): 631-647. https://doi.org/10.1108/MEQ-07-2013-080.

Suryana, A., dan Aguatian, A. 2014. Analisis Dayasaing Usahatani Jagung di Indonesia. Analisis Kebijakan Pertanian. Vol. 12 (2): 143-156. http://dx.doi.org/10.21082/akp. v12n2 .2014.143-156

Susilawati, S. H., Sinaga M., Wilson, H.L., dan Erwidodo. 2007. Dampak Kebijakan Ekonomi di Sektor Agroindustri terhadap Kemiskinan dan Distribusi Pendapatan. Jurnal Agro Ekonomi. Vol. 25 (1): 11-36. http://dx.doi. Org/10.21082/ jae.v25n1. 2007.11-36

Sutomo, Y. P., dan Istiqomah, N. 2015. Analisis Dampak Alih Fungsi Lahan terhadap Tingkat Ketahanan Pangan Rumah Tangga Petani di Karanganyar, Jawa Tengah. AGRARIS. Vol. 1 (2): 98-107. http://DOI:10.18196/agr.1213.

Ullah, A.K.M. Ahsan, dan Jayant K. Routray. 2007. Rural Poverty Alleviation through NGO Interventions in Bangladesh: How far is the Achievement?. International Journal of Social Economics. Vol. 34 (4): 237-248. https://doi. org/10.1108/0306829071073428.

UU Nomor 18 Tahun 2012 tentang Pangan.

Wijaya, I. R. A., Masyhuri, Irham, dan Hartono, S. 2014. Analisis Input Output Pengolahan Tembakau di Provinsi Jawa Timur. Agro Ekonomi. Vol. 24 (1): 1-9. https://doi.org /10.22146/ agroekonomi. 17355 .

Wijaya, O. 2017. Strategi Pengembangan Komoditas Pangan Unggulan dalam Menunjang Ketahanan Pangan Wilayah (Studi Kasus di Kabupaten Batang, Propinsi Jawa Tengah). AGRARIS. Vol. 3 (1): 48-56. http://DOI: 10.18196/agr.3144.

Widodo, T. 2006. Perencanaan Pembangunan: Aplikasi Komputer (Era Otonomi Daerah). Yogyakarta: UPP STIM YKPN.

\section{BIODATA PENULIS:}

Tuminem dilahirkan di Wonogiri tanggal 8 Juli 1981. Penulis menyelesaikan pendidikan S1 pada Jurusan Budidaya Pertanian Fakultas Pertanian, Universitas Sebelas Maret Surakarta tahun 2005 dan Pendidikan S2 pada Program Studi Agribisnis, Program Pascasarjana, Universitas Sebelas Maret Surakarta tahun 2015-2018.

Suprapti Supardi dilahirkan di Sragen tanggal 8 Agustus 1948. Penulis menyelesaikan pendidikan S1 Bidang Ilmu Pertanian di Universitas Gajah Mada pada tahun 1974, pendidikan S2 Bidang IImu Pertanian Universitas Gajah Mada tahun 1994, dan pendidikan S3 Bidang Ilmu Pertanian, Universitas Gajah Mada tahun 2002.

Minar Ferichani dilahirkan di Yogyakarta tanggal 31 Maret 1967. Penulis menyelesaikan pendidikan S1 di Bidang IImu Peternakan, Universitas Gajah Mada tahun 1992, pendidikan S2 Bidang IImu Pertanian Universitas Gajah Mada tahun 1998, dan pendidikan S3 Bidang IImu Ekonomi Pertanian, Universitas Gajah Mada tahun 2007. 